\title{
Analisis Wacana Kritis Teks Berita \\ Kasus Terbongkarnya Perlakuan Istimewa terhadap Terpidana Suap Arthalyta Suryani pada Media Online
}

\author{
Hetty Catur Ellyawati \\ (1tlantip@gmail.com) \\ Dosen Jurusan Ilmu Komunikasi Universitas Semarang
}

\begin{abstract}
Every choice of meaning is ideologically motivated. Ideology is most effective when its working is least visible. Interpreting ideology in a text can be seen from the choice of vocabulary and its grammatical construction. To analyze it we need to interpret not just the text but also the relationship between text, and its social condition. According to Fairclough, they can be grouped in three steps, those are description, interpretation and explanation. The stage of description is concerned with formal properties of the text, the interpretation is concerned with the relationship between text and its interactions, the explanation is concerned with the relationship between interpretation and social context.

This research aims to analysis the coverage about the revealed case of preferential treatment of Arthalyta Suryani, a convicted bribe, at Pondok Bambu detention written by two online media these are detikNews.com and kompas.com by analyzing their appraisal system and their intertextuality. From the data analysis, ideology of the two media about this case can be seen. The data is taken from the news posted on January the tenth to twelfth 2010.

The methods used to analyze the data are referential method, substitusional method and abductive inference method. Referential method is to analyze appraisal system and discursivity intertextuality of the text. In order to make the analysis of appraisal system valid, the substitusional method is needed. Then abductive inference method is needed to analyze manifest intertextuality of the text.

From the analysis of the data, it can be concluded that every media has its own way to state its ideology. The ideology has closed relation with target market that is the reader. DetikNews.com is strightforward and short news, with incisive vocabulary choices, they are related to news item genre that detikNews.com has, but this media is lack of intertextuality. It makes the news superficial. On the other way, kompas.com has a deep coverage and strong intertextuality, it is suitable for someone who wants comprehensive information.
\end{abstract}

Keywords: Analisis Wacana Kritis (CDA), Ideologi, Appraisal System (Sistem Appraisal), Intertextuality (Intertekstualitas)

\section{Pendahuluan}

\section{Masalah Penelitian}

Setiap media memiliki ideologi dalam pemberitaan. Menurut Eriyanto (2001) ideologi sebuah media dapat diamati melalui pilihan bahasa serta struktur gramatika yang digunakan dalam penulisan berita. Ideologi ini biasanya disesuaikan dengan target pembaca sebagai konsumen berita. Kesamaan ideologi antara media serta pembacanya dianggap penting sebagai bagian dari legitimasi dominasi media terhadap khalayak pembaca. Dengan 
memiliki ideologi yang sama, diharapkan liputan berita yang diturunkan seorang jurnalis melalui sebuah media dapat diterima secara 'taken for granted' oleh pembacanya.

Penelitian ini berusaha untuk mengidentifikasi ideologi media online yang diwakili oleh Kompas.com dan detikNews.com pada liputan berita terbongkarnya perlakuan istimewa terhadap terpidana suap Arthalyta Suryani di Rutan Pondok Bambu melalui penggunaan bahasa pada liputan beritanya.

Pemilihan dua media online tersebut karena keduanya memiliki karakter serta orientasi pemberitaan yang sangat berbeda. Seperti diketahui bahwa orientasi detikNews.com adalah pada kecepatan penurunan liputan berita dengan pilihan kata-kata yang menyengat, sedangkan orientasi media kompas.com adalah pada mutu dan sifat elegan teks berita. Berita-berita yang diturunkan selalu hati-hati, terpercaya, tidak mudah menyebar isu.

\section{Lingkup Penelitian}

Penelitian ini termasuk dalam ancangan studi analisis wacana kritis (CDA), yaitu sebuah studi yang tidak hanya menganalisis pemakaian bahasa dalam tuturan dan lisan tetapi melihat bahasa sebagai praktik sosial. Pengkaitan ini menyebabkan terjadinya hubungan dialektis antara wacana dengan situasi, institusi serta struktur sosial yang membentuk wacana tersebut (Eriyanto (2001: 7).

Lebih konkret lagi, penelitian ini melihat pilihan kata (kosakata) suatu teks. CDA melihat bagaimana pilihan kata bisa membawa posisi dan makna ideologi tertentu. Dengan kata lain, ideologi diamati dengan melihat pada pilihan kata yang dipakai. Pembahasannya terpusat pada kajian SFL (Systemic Functional Linguistics) yaitu pada ranah makna interpersonal, khususnya pada sistem appraisal, karena CDA (Critical Discourse Analysis) mempunyai hubungan yang amat dekat dengan SFL, bahwa setiap pemilihan makna dari suatu teks pasti dimotivasi oleh ideologi tertentu. Hal ini diungkapkan oleh Martin, J.R dan David Rose (2003: 263) ${ }^{1}$. SFL merupakan kajian yang tidak hanya berusaha mengidentifikasi struktur tetapi juga mencari tahu bagaimana sebuah struktur kata mengkonstruksi makna, titik beratnya adalah pada pertanyaan 'bagaimana sebuah makna teks diwujudkan' sehingga bisa dikatakan fokus SFL tidak hanya pada teks yang dibangunnya semata tetapi juga pada konteks teks tersebut.

Selain pada tataran kosakata, penelitian ini juga mengkaji hubungan antar teks. Analisisnya adalah pada hubungan yang mengikat teks menjadi satu kesatuan dalam teks. Fokus yang lain adalah pada hubungan teks dengan konteks sosial yang melatar belakangi munculnya teks tersebut. Pada konsep Fairclough, hubungan antar teks terdapat pada tahap interpretasi, sedangkan hubungan antar teks dengan konteks sosial termasuk dalam tahap eksplanasi.

\section{Tujuan Penelitian}

Secara umum, tujuan penelitian ini adalah untuk mengidentifikasi serta menjelaskan ideologi teks pada liputan berita terbongkarnya kepemilikan sel mewah oleh Arthalyta Suryani pada media online yaitu detikNews.com dan kompas.com yang disesuaikan dengan target market kedua media tersebut melalui tahapan analisis wacana kritis model Fairclough dengan melihat pada aspek kosakata, yaitu pada penggunaan

\footnotetext{
${ }^{1}$ Pada konsep Fairclough, analisis CDA pada tataran gramatikal atau formal teks termasuk pada tahap deskripsi.
} 
sistem appraisal serta aspek genre teks. Bahasan ini ditujukan untuk melihat fungsi sosial teks dan aspek intertekstualitas teks. Kajian ini bermaksud melihat hubungan dalam dan antar teks berita.

\section{Landasan Teori}

Tahapan Analisis CDA (Critical Discourse Analysis) menurut Fairclough

Penelitian ini menggunakan

landasan teori Fairclough (1989)

tentang prosedur analisis wacana kritis yang tahapnya terdiri atas tiga, yaitu deskripsi, interpretasi dan eksplanasi (Fairclough, 1989: 26).

Analisis teks pada tahap deskripsi mengacu pada tingkatan yang berhubungan dengan sifat formal teks, kajiannya meliputi aspek kosakata dan gramatikal yang tercakup pada aspek makna eksperensial (ideasional), interpersonal serta makna tekstual teks, sedangkan aspek struktur teks ada pada analisis genre. Atau secara global, bisa dikatakan bahwa tahapan deskripsi adalah tahapan yang mengacu pada fitur-fitur linguistik.

Tahap interpretasi berkaitan dengan hubungan antara teks dan interaksi dalam teks yaitu dengan melihat teks sebagai suatu produk proses produksi, dan sebagai sumber dalam proses interpretasi. Tahap ini merupakan tahap yang mengikutkan faktor-faktor sosial (interpretasi konteks) dari suatu teks, misalnya saja tentang siapa yang terlibat, apa yang sedang terjadi, dalam hubungan apa, serta apa peran bahasa pada teks tersebut, selanjutnya baru ditentukan interpretasi teksnya berdasarkan hubungannya dengan interpretasi konteks tersebut. (Fairclough, 1989: 146-148).

Dijelaskan lebih detail oleh Fairclough (1989: 141) bahwa interpretasi adalah penggeneralisasian melalui apa yang ada dalam teks dan apa yang ada dalam benak si interpreter serta dalam kerangka berpikir members of resourses ${ }^{2}$ atau jika digambarkan adalah sebagai berikut:

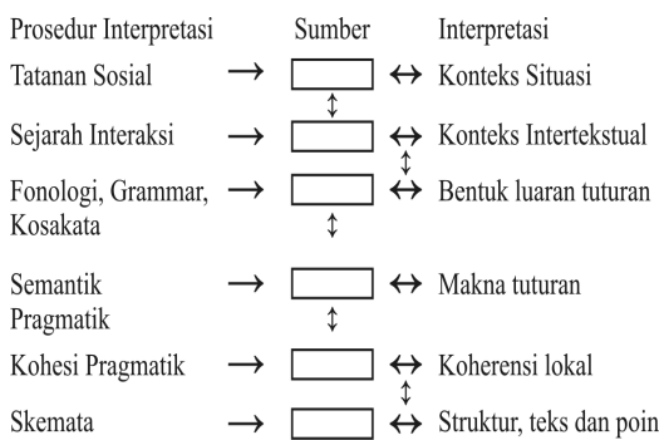

Tahapan selanjutnya adalah eksplanasi. Tahap ini berkaitan dengan hubungan antara konteks interaksi dan sosial. Tahapannya berhubunganan dengan penentuan sosial proses produksi dan interpretasi serta efek-efek sosial pada terwujudnya sebuah teks. Pertanyaan yang muncul pada tahap ini biasanya adalah apa yang membantu terbentuknya sebuah wacana yang berhubungan dengan penentuan sosial yang meliputi level situasional, institusional dan kemasyarakatan. Sedangkan pada level ideologi, pertanyaan yang muncul adalah elemen apa yang digambarkan memiliki muatan ideoligis. 


\section{Konteks}

Sebelum menginterpretasi teks, diperlukan interpretasi konteks yang meliputi teks. Yang dimaksud dengan konteks di sini adalah konteks situasi (Halliday dan Hasan, 1985: 16) yang terdiri atas: field, tenor dan mode.

Field merupakan medan dalam suatu wacana yang mengacu pada hal apa yang sedang terjadi dalam teks serta tindakan sosial yang sedang berlangsung. Tenor merupakan pelibat suatu wacana yang mengacu pada siapa yang terlibat dalam teks tersebut, kepada siapa teks tersebut ditujukan, serta apa hubungan yang terjadi antar pelaku dalam wacana, misalnya status dan kekuasaan partisipan, afeksi (suka atau tidak suka atau netral), kontak (frekuensi dan durasi kontak, kedekatan). Mode, merupakan sarana dalam suatu wacana, menunjukkan pada bagian yang menjadi tujuan yang akan dicapai tenor, misalnya pada bagaimana

\begin{tabular}{|l|l|l|}
\hline \multicolumn{2}{|c|}{ Opsi affect } \\
\hline Jenis & Kategori & Contoh \\
\hline Positif & & Kami bahagia \\
\hline negatif & & Hati saya berkeping-keping \\
\hline langsung & pernyataan emosional & benar-benar bahagia \\
\hline & pernyataan secara fisik & pendiam \\
\hline & Pernyataan dengan ekspresi & berjabat tangan dengan dengan tidak terkontrol \\
\hline tidak langsung & extraordinary & mengembara dari satu jendela ke jendela yang lain \\
\hline & behavior & menggeliat dari sisi tempat tidur \\
\hline & metafor & mata...tumpul seperti mati \\
\hline
\end{tabular}

\section{b. Penilaian Karakter (Judgement of People's Character)}

Judgement berkaitan dengan penilaian, baik positif maupun negatif yang disampaikan secara langsung maupun tidak langsung. Terdapat dua penilaian yaitu pribadi, yang ditujukan pada karakter pribadi seseorang dan moral, yang biasanya ditujukan pada kebijakan yang dibuat seseorang yang menyangkut kepentingan orang banyak. bahasa digunakan yaitu tulis atau lisan, bahasa digunakan sebagai aksi atau sebagai refleksi.

\section{Sistem Appraisal}

Sistem appraisal merupakan sistem evaluasi yang menyatakan sikap atau makna yang ada dalam suatu wacana atau teks, yang mempunyai kekuatan emosional yang dapat membuat suatu teks bermakna bagi pembaca.

Menurut Martin dan Rose (2003: 22-65) terdapat tiga aspek dalam sistem appraisal yaitu attitudes, amplified dan source).

\section{Attitudes}

a. Ekspresi Perasaan (Affect)

Affect digunakan untuk mengekspresikan perasaan, baik yang positif maupun yang negatif, dalam menyampaikan perasaan dapat diekspresikan secara langsung maupun tidak langsung.

\begin{tabular}{|l|l|l|l|}
\hline \multicolumn{5}{|c|}{ Penilaian Terhadap Karakter Seseorang } \\
\hline Jenis & Kategori & Langsung & Tidak Langsung \\
\hline Personal & memuji & populer, enerijk & bekerja pada level atas \\
\hline & mengkritik & saya tidak tahan dengannya & saya tidak bisa menjelaskan rasa saya \\
\hline Moral & Memuji & Pemimpin kita pemberani & saya menghorrmati perjuangan itu \\
\hline & Menyalahkan & Kalau saya sih, akan saya pecat & ini harus kita perangi \\
\hline
\end{tabular}

\section{c. Penghargaan (Appreciation)}

Appreciation atau penghargaan muncul karena tindakan atau perilaku seseorang terhadap sesuatu, biasanya berupa abstrak. Terdapat appreciation positif dan negatif. Misalnya: a beautiful relationship (positif), unsuccessful marriage (negatif).

\section{Amplified}

Amplified merupakan tingkatan pernyataan mengenai perasaan penulis terhadap apa yang sedang dirasakan. Tingkatan perasaan tersebut dapat berupa pujian, kiasan, sanjungan atau 
sindiran yang bersifat diperkuat kuat (sharpen) atau diperlembut (soften).

\section{Source}

Source berkaitan dengan 'dari siapa evaluasi berasal?'. Terdapat beberapa source menurut Kristeva yang dikutip oleh Martin dan Rose (2003: 44) yaitu heterogloss, bila sumber berasal dari banyak sumber bukan hanya dari penulis saja. Monogloss, bila sumber hanya berasal dari penulis. Pada source heterogloss terdapat tiga macam jenis yaitu:

\section{a. Projecting source}

Salah satu cara yang dapat kita lakukan pada suatu teks adalah dengan mengutip atau melaporkan (report) apa yang orang lain katakan atau pikirkan. Hal ini dapat dilakukan dengan empat cara yaitu:

- Projecting clauses: menyatakan apa yang menjadi dasar sesuatu terjadi

- Names of speech act: menyatakan apa tujuan sesuatu tersebut dimunculkan, serta apa manfaat yang dapat dihasilkan oleh projecting source.

- Projecting within clause: pernyataan apa yang membuat orang banyak dapat dipersuasi.

- Scare Quotes: pesan apa yang disampaikan kepada orang banyak.

\section{b. Modalitas (Modality)}

Modalitas mempunyai hubungan dengan amplifikasi (implified) karena sama-sama membahas mengenai penyangatan. Terdapat dua jenis modalitas, yaitu modalitas untuk negosiasi servis dan modalitas untuk negosiasi informasi. Pada permintaan servis,

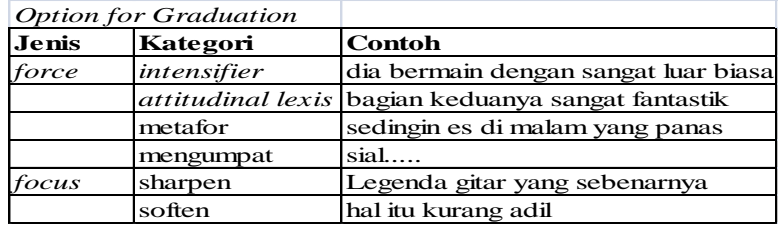

modalitas dapat dinegosiasikan sebagai berikut:

Do it

You must do it

You should do it

You could do it

Don't do it

Kalimat semakin ke bawah, semakin negatif derajatnya, sehingga kalimat yang paling positif adalah kalimat yang berada di posisi atas, sedangkan yang paling negatif adalah yang berada di paling bawah. Artinya, semakin ke atas, semakin tinggi derajat keharusan seseorang melakukan servis yang diminta.

Di lain pihak, pernyataan yang memberi informasi dapat dinegosiasikan sebagai berikut:

It is

It must be

It should be

It might be

It isn't

Semakin ke atas, semakin positif derajatnya, artinya semakin pasti informasi tersebut.

\section{c. Concession}

Kategori yang terakhir ini berhubungan dengan penggunaan konjungsi dalam kalimat, misalnya but, even if, in fact, suddenly, even, only dan lainnya.

\section{Genre Teks}

Menurut Eriyanto (2002: 91) berita pada dasarnya dibentuk lewat proses aktif dari pembuat berita. Peristiwa yang kompleks dan tidak beraturan disederhanakan dan dibuat bermakna oleh pembuat berita. Semua proses tersebut melibatkan proses lewat skema interpretasi dari pembuat berita. 
Fishman menambahkan, yang dikutip oleh Eriyanto (2002: 91) bahwa peristiwa adalah sebuah fenomena atau kejadian yang diinterpretasikan, sesuatu yang diorganisasikan dalam pikiran, ucapan dan tindakan. Karena itu, peristiwa yang kompleks tersebut diinterpretasikan dalam skema pembuat berita. Fishman misalnya memberi ilustrasi yang menarik mengenai seorang anak yang hilang. Peristiwa ini dapat disusun dalam kerangka yang berbeda-beda dan diatur ke dalam struktur cerita yang bermacam-macam. Demikian halnya dengan berita, satu berita yang sam dapat disusun ke dalam struktur cerita yang berbeda-beda tergantung pada keinginan penulis berita tentang sisi mana dari berita tersebut yang ingin ditonjolkan.

Terdapat banyak sekali tipe genre (struktur cerita) pada teks menurut Gerot and Wignell (1994: 190-248), tetapi yang akan dijelaskan di sini hanya dua tipe genre yang sesuai dengan dua tipe genre yang dimiliki oleh teks yang akan dianalisis pada penelitian ini.

\section{a. Deskripsi}

Genre jenis ini bertujuan untuk menjelaskan orang, tempat atau sesuatu secara khusus dan mendetail. Generic structurenya (skema) adalah sebagai berikut:

Identifikasi mengidentifikasi fenomena yang hendak dijelaskan

deskripsi : mendeskripsikan bagian, kualitas atau karakter.

\section{Fitur leksikogramatikal yang mungkin ada:}

Fokus pada partisipan tertentu

Menggunakan proses atributif dan identifikasi

Kadang menggunakan julukan (epithets) dan penggolongan (classifiers) pada kelompok nominalnya.
Menggunakan bentuk kala simple present

b. Item Berita (News Item)

Tipe ini mempunyai tujuan untuk menginformasikan pada pembaca atau pendengar atau pengamat tentang suatu kejadian hari itu yang dianggap layak menjadi berita atau dianggap penting. Struktur skemanya adalah sebagai berikut:

Hal yang dianggap penting : berisi ringkasan cerita

Latar belakang : berisi rincian berita, apa yang terjadi, pada siapa, dengan keadaan yang bagaimana.

Sumber : komentar para partisipan, saksi atau ahli dalam peristiwa tersebut.

Fitur leksikogramatikal yang mungkin ada:

Informasi pendek mengenai berita yang tertera di headline

Menggunakan proses material untuk menceritakan kembali kejadian.

Menggunakan proses verbal pada tahap sumber

Fokus pada keadaan (circumstances).

\section{Intertekstualitas (Intertextuality)}

Intertekstualitas merupakan hubungan teks dalam suatu teks atau hubungan teks dalam suatu ranah yang lebih besar yang membentuk teks. Diterangkan lebih lanjut oleh Bakhtin dalam Fairclough (1992: 103) yang mengutip pendapat Kristeva (1986: 36) bahwa terdapat dua dimensi intertekstualitas, yaitu horizontal dan vertikal. Dimensi horizontal merupakan hubungan antara teks sebelum teks dan teks sesudah teks. Sedangkan dimensi vertikal membahas tentang hubungan teks dengan teks lainnya yang berasal dari genre yang berbeda. Pada hubungan vertikal, teks dihubungan secara langsung (straighforward) ataupun dengan cara menekankan 
bagian yang dianggap penting (reaccentuate) secara ironi maupun parodi. Sedangkan Renkema (1993: 3536) memberi keterangan yang lebih sederhana mengenai intertesktualitas yaitu mengacu pada rangkaian kalimat yang berhubungan secara bentuk dan arti dengan rangkaian kalimat yang lain.

Terdapat empat cara untuk menciptakan intertesktualitas menurut http://www.answers.com/topic/literacyintertextuality:

a. Duplikasi (serangkaian kata-kata yang ada dalam dua teks- kutipan) secara stilistik (repetisi dari pola tekanan, suara, atau pola sajak di dua atau lebih teks).

b. Penamaan dan referensi (seperti yang terjadi dalam kutipan)

c. Asosiasi proksimal (seperti yang terjadi di antara bab-bab dalam sebuah buku yang diedit dianggap memiliki hubungan satu sama lain)

d. Asosiasi sekuensial (misalnya hubungan yang ada pada surat balasan atau email).

\section{Metode \\ Sumber Data}

Sumber data penelitian ini adalah teks berita dari dua media online yaitu media detikNews.com dan kompas.com pertanggal 10 Januari 2010 hingga 12 Januari 2010 yang diunduh dari internet. Pembatasan tanggal pada pengumpulan data dilakukan untuk memudahkan analisis data karena unit analisis penelitian ini hingga pada tahap klausa.

Pemilihan detikNews.com serta kompas.com sebagai sumber data penelitian ini adalah karena kedua media online tersebut memiliki perbedaan orientasi pemberitaan yang sangat mencolok. detikNews.com memiliki orientasi pada kecepatan penurunan berita tetapi kadang mengabaikan kualitas berita, ini bisa dilihat dari beberapa liputan berita tentang terbongkarnya kepemilikan sel mewah oleh Arthalyta Suryani, terdapat beberapa informasi yang sama yang diulang yang diturunkan pada menit yang berbeda. Sedangkan kompas.com cenderung menitikberatkan pada kualitas berita terutama keobyektifan berita, sehingga liputannya terkesan netral dan sangat hati-hati, tetapi keuptodatean beritanya kurang bisa diandalkan, hal ini bisa dilihat pada tanggal penurunan liputan berita tentang terbongkarnya kepemilikan sel mewah oleh Arthalyta Suryani, detikNews.com telah menurunkan berita tentang kasus tersebut pertanggal 10 Januari 2010 pukul 21:19 WIB, sedangkan kompas.com baru menurunkannya tanggal 11 Januari 2010 pukul 06:21 WIB.

\section{a. Populasi}

Populasi pada penelitian ini adalah teks berita yang diambil dari detikNews.com pertanggal 10-11 Januari 2010 sebanyak 35 berita, serta teks berita kompas.com pertanggal 1112 Januari 2010 sebanyak 25 berita.

Perbedaan tanggal pengambilan populasi berita pada media detikNews.com serta kompas.com dikarenakan tanggal turunnya atau dipublikasikannya berita masingmasing media berbeda. detikNews.com mulai menurunkan berita tentang kasus terbongkarnya keberadaan sel mewah di Rutan Pondok Bambu yang dimiliki Arthalyta Suryani adalah tanggal 10 Januari 2010 pukul 21: 29 WIB, sedangkan kompas.com baru menurunkan berita pertamanya mengenai kasus tersebut pada tanggal 11 Januari 2010 pukul 06:21 WIB.

\section{b. Sampel}

Teknik yang digunakan dalam pengambilan sampel pada penelitian ini 
adalah purposive sampling artinya pemilihan sampel penelitian disesuaikan dengan kebutuhan peneliti.

Dari hasil purposive sampling diambil 15 sampel teks berita dari kompas.com sebagai sampel, serta 22 teks berita dari detikNews.com.

Penamaan sampel (pengkodean) dilakukan sesuai dengan tanggal diturunkannya berita tersebut, misalnya teks berita berjudul "Satgas Mafia Hukum Sidak Kamar Ayin di Rutan Pondok Bambu" yang diturunkan tanggal 10 Januari 2010 pukul 21:19 WIB oleh detikNews.com maka akan ditulis dengan 10/21:19/detik.

\section{Teknik Penyajian}

Pada penelitian ini, terdapat dua teknik yang digunakan untuk penyajian data. Yang pertama adalah teknik formal. Teknik ini berkaitan dengan penggunaan kaidah-kaidah yang menghubungkan unsur-unsur konkret dari suatu sistem yang abstrak dengan model yang berasal dari sistem itu sendiri (Mastoyo, 2007: 73). Teknik penyajian formal pada penelitian ini digunakan untuk penyajian hasil analisis formal teks yaitu pada identifikasi makna ideasional, tekstual serta interpersonal teks.

Teknik yang kedua adalah teknik informal. Teknik ini berkenaan dengan penggunaan kata-kata biasa yang apabila dibaca dengan serta merta maka akan langsung dipahami isinya (Mastoyo, 2007: 71). Teknik penyajian informal ini digunakan pada penyajian hasil analisis data interaksi teks (intertekstualitas) serta identifikasi genre teks.

\section{Teknik Analisis Data}

Terdapat tiga metode yang digunakan dalam analisis data. Yang pertama adalah metode padan referensial. Metode ini digunakan bila alat penentunya berupa referensi bahasa (Mastoyo, 2007: 48). Pada analisis data, metode padan referensial digunakan pada analisis sistem appraisal serta struktur teks atau genre. Pada analisis appraisal selain digunakan metode padan referensi, juga digunakan metode agih substitusi, yaitu metode yang mensubstitusi atau mengganti bagian data yang dianalisis dengan data yang lain untuk melihat kevalidan analisis data tersebut.

Metode yang ketiga adalah inferensi (inferences) atau penarikan kesimpulan. Jenis inferensi yang digunakan adalah abduktif inferensi (abductive inferences) yaitu penarikan kesimpulan dengan cara menghubungkan satu teks ke teks yang lain (Krippendorff, 2004: 36). Metode ini digunakan pada analisis intertekstualitas teks. Pada analisis ini, teks akan dihubungkan sedemikian rupa sehingga dengan teks lain yang mendukung teks sebelumnya.

\section{Prosedur Penelitian}

Berikut adalah beberapa prosedur penelitian yang penulis lakukan:

a. Data dikumpulkan, kemudian dikelompokkan mana yang merupakan teks berita dari detiknews.com dan mana yang merupakan liputan kompas.com.

b. Kedua teks dianalisis untuk mengidentifikasi penggunaan sistem appraisalnya.

c. Teks dianalisis bentuk strukturnya (genre) untuk mengetahui tujuan penulisan teks.

d. Teks diidentifikasi intertekstualitasnya untuk mengetahui hubungan teks dengan teks sebelum dan sesudahnya.

e. Dibuat simpulan hasil analisis data.

\section{Pembahasan}

Temuan Hasil Analisis 
Dari hasil analisis data teks terbongkarnya perlakuan istimewa terhadap terpidana suap Arthalyta Suryani pada dua media online yaitu detikNews.com dan kompas.com yang dikaitkan dengan ideologi kedua media tersebut ditemukan bahwa media detikNews.com bersikap lebih memberi apresiasi negatif pada sosok Arthalyta Suryani. Hal ini dapat dilihat dari hasil analisis sistem appraisal yang digunakan media tersebut. Sedangkan, media kompas.com bersikap lebih netral dengan mengupas seluruh aspek yang berkaitan dengan kasus terbongkarnya perlakuan istimewa yang diterima Ayin di Rutan Pondok Bambu yaitu dengan menyoroti kasus terbongkarnya perlakuan istimewa itu sendiri, sel-sel mewah yang ada di Rutan tersebut, serta pihak-pihak yang bertanggung jawab atas adanya perlakuan istimewa tersebut. Simpulan ini juga terlihat pada hasil analisis sistem appraisal yang digunakan media kompas.com. Sikap memberi apresiasi negatif milik detikNews.com maupun sikap netral kompas.com pada kasus terbongkarnya perlakuan istimewa atas terpidana suap Arthalyta Suryani tersebut sesungguhnya mencerminkan ideologi masing-masing media yaitu detikNews.com yang memiliki ideologi selalu mengedepankan berita-berita yang aktual dengan liputan dan bahasa yang tajam. Dalam hal ini, detikNews.com memilih kosakatakosakata yang tajam untuk menggambarkan sosok Arthalyta Suryani yang sedang berada dalam penjara. Dilain pihak, kompas.com memiliki ideologi untuk mengedepankan komprehensitas liputan berita dengan tidak terburu-buru memberi penilaian positif maupun negatif terhadap suatu kasus namun memilih untuk lebih bersikap netral dengan menjelaskan seluruh fakta yang ada dan membiarkan pembaca yang menilai. Sikap ini nampak pada hasil analisis sistem appraisal yang digunakan.

Sedangkan pada analisis genre teks, ditemukan bahwa genre teks detikNews.com bersifat news item. Dipilihnya sosok Ayin sebagai bahan berita oleh detikNews.com membuktikan sifat news item media ini. Sedangkan kompas.com yang menjelaskan secara komprehensif semua aspek yang berhubungan dengan kasus terbongkarnya perlakuan istimewa terhadap terpidana suap Arthalyta Suryani menggambarkan genre teks media ini yang bersifat deskriptif.

Pada bahasan intertekstualitas ditemukan bahwa tidak terdapat intertekstualitas yang kuat pada teksteks berita detikNews.com karena berita-berita detikNews.com mengedepankan keaktualitasan, sehingga topik apa yang dianggap menarik saat itu, itulah yang akan dibahas. Sebaliknya, jalinan intertekstualitas pada berita-berita kompas.com sangat terlihat jelas dan kuat.

\section{Sistem Appraisal}

Pada sistem appraisal terdapat 3 hal yang dibahas yaitu attitude, amplified dan source. Pada media detikNews.com maupun kompas.com terdapat 2 source appraisal yang pertama adalah dari penulis (wartawan yang menulis berita) dan yang kedua adalah dari nara sumber yang dikutip pendapatnya. Sedangkan objek dari penyampaian appraisal ada tiga yang pertama adalah Arthalyta Suryani dan yang kedua adalah sel mewah yang dimiliki Ayin di Rutan pondok bambu serta kasus terbongkarnya perlakuan khusus itu sendiri. Namun terdapat perbedaan appraisal pada kedua media 
online di atas, yaitu, pada detikNews.com, tujuan penyampaian appraisal lebih dominan pada sosok Arthalyta Suryani dengan attitude nya, sedangkan pada media kompas.com,

\section{a. Appraisal untuk Arthalyta Suryani yang bersumber dari wartawan maupun nara sumber pada media detikNews.com}

Pada tabel 1 di atas terdapat 3 contoh kalimat yang mengandung appraisal yang ditujukan pada Arthalyta Suryani alias Ayin yang berasal dari wartawan dan satu kalimat yang berasal dari nara sumber. Sekilas tidak ada yang aneh dengan kalimatkalimat di atas, tetapi bila kita lihat konteks situasi kalimat tersebut, maka baru akan terasa ada muatan memperhalus, mengkritik yang ditujukan pada sosok Ayin.

\section{Kalimat 1 tabel 1.}

Kalimat 1 pada tabel 1 ditulis wartawan saat menurunkan liputan tentang bagaimana terkejutnya Arthalyta Suryani saat tiba-tiba sel mewah yang dimilikinya di Rutan Pondok Bambu disidak oleh tim anti mafia hukum bentukan SBY. Di liputan tersebut diturunkan kutipan nara sumber yaitu Syamsu, seorang pengacara yang pernah menangani kasus sengketa tanah PT Harangganjang dengan PT GMN milik Arthalyta Suryani. Saat itu Ayin sedang dalam penjara, namun dia mampu membuat 'terobosan' hukum sehingga tanah seluas $5.100 \mathrm{~m}^{2}$ yang awalnya dimiliki oleh PT Harangganjang tiba-tiba berpindah tangan menjadi milik PT GMN. Menurut kesaksian Syamsu 'terobosan' hukum yang dimaksud adalah bahwa Ayin melakukan pendekatan- appraisal banyak digunakan untuk mengapresiasi kasus terbongkarnya perlakuan istimewa pada tahanan di Rutan Pondok Bambu. Berikut adalah contohnya:

\begin{tabular}{|c|c|c|c|}
\hline & Jenis Appraisal & contoh & Prosentiase \\
\hline 1 & $\begin{array}{l}\text { Amplified: soften, source: wartawan } \\
\text { Amplified: soften, source: nara sumber }\end{array}$ & $\begin{array}{l}\text { merasakan kehebatan Ayin (11/19:22) } \\
\text { Ayin membuat terobosan hukum (11/19:22) }\end{array}$ & $18 \%$ \\
\hline 2 & Affect: judgement: mengkritik & Tampil eye catching (11//2:59) & $45 \%$ \\
\hline \multirow[t]{3}{*}{3} & Affect: pernyataan langsung dengan ekspresi & tergopoh-gopoh ke lapangan sambil & $36 \%$ \\
\hline & & membawa gelas kaca berisi susu (11/11:40) & \\
\hline & & Jumlah & $100 \%$ \\
\hline
\end{tabular}

pendekatan dan sejumlah upaya hukum pada Pemprov DKI Jakarta agar mau menerbitkan SIPT dan HGB kepada PT GMN atas tanah seluas $5.100 \mathrm{~m}^{2}$ tersebut.

Kata 'kehebatan' pada kalimat 1 tabel 1 sesungguhnya mengacu pada kata 'kelicikan' bila berkonotasi negatif dan 'kemampuan atau kepandaian' bila berkonotasi positif. Yang dimaksud wartawan dengan menulis 'kehebatan' (mengacu pada apa yang telah dilakukan Ayin pada kasus sengketa tanah tersebut) adalah makna yang berkonotasi negatif tetapi diperhalus dengan menggunakan istilah 'kehebatan'. Demikian juga pada penggunaan kata 'terobosan', kata ini juga dapat mengacu ke makna negatif 'kelicikan' atau 'kepandaian' atau kata lain yang bermakna negatif untuk mengacu pada upaya-upaya yang telah Ayin lakukan untuk membuat tanah seluas $5.100 \mathrm{~m}^{2}$ menjadi milik PT GMN miliknya.

\section{Kalimat 2 dan 3 tabel 1.}

Kalimat 2 pada tabel 1 mengacu pada sosok Ayin yang selama di penjara lebih sering berpenampilan eye catching daripada berpenampilan sekedarnya seperti umumnya orang yang sedang berada dalam masa tahanan. Atau pada liputan yang lain dikatakan Ayin selalu bermake up tebal (10/23:07/detik). 
Pencitraan-pencitraan ini memiliki makna negatif bagi Arthalyta Suryani bila dilihat dari konteks situasi kalimat yaitu seseorang yang berada dalam penjara, tetapi masih berpenampilan mencolok mata (dalam hal make up), tampak santai menggunakan jeans (11/11:25/detik) atau pada kalimat 'yang mendominasi kamar sel Ayin adalah alat-alat kosmetik' (11/12:59/detik), 'kamar berukuran 3x6 meter yang dilengkapi dengan peralatan modern' (11/12:59/detik). Pencitraanpencitraan ini seakan-akan ingin menggiring pembaca untuk membayangkan sosok seperti apakah Ayin yang sedang berada dalam sel sekarang.

Ini dikontraskan lagi dengan kalimat berikut, 'kita ke sel-sel umum, sangat bertumpuk' (11/01:30/detik) yang mengacu pada pendapat seorang nara sumber yang sangat kaget melihat perlakuan khusus yang diterima Arthalyta Suryani di penjara. Kata 'bertumpuk' berasosia dengan keadaan sel yang kumuh, sempit, namun dihuni banyak orang sehingga menimbulkan rasa tidak nyaman, tidak sehat karena fasilitas yang sangat sederhana, sangat terbatas dan ini benar-benar berlawanan dengan gambaran sel Ayin yang berukuran $3 \times 6$ meter yang dilengkapi

\section{b. Appraisal pada media kompas.com}

Pada tabel 2 terdapat 3 contoh kalimat yang menggunakan appraisal. Ketiganya ditujukan untuk objek yang berbeda. Kalimat 1 ditujukan pada tahanan yang berada di Rutan Pondok Bambu, kalimat ke 2 ditujukan pada kasus terbongkarnya perlakuan istimewa terhadap tahanan di Rutan tersebut dan kalimat ke 3 ditujukan pada kamar mewah tahanan. Tahanan yang dimaksud di sini tidak hanya peralatan modern serta sikap Ayin yang nampak santai dengan jeans dan make up tebal apalagi memegang gelas kaca yang berisi susu. Semua orang juga mengerti bahwa susu merupakan minuman yang masih dianggap 'kelas tinggi' di Indonesia, artinya hanya orang-orang kaya atau yang mampu saja yang bisa menikmati minuman ini karena harganya yang lumayan mahal, tetapi Ayin yang berada di penjara masih dapat menikmatinya dengan mudah karena perlakuan-perlakuan khusus yang ia terima di penjara.

Pencitraan-pencitraan inilah yang membuat peneliti berkesimpulan bahwa pada liputan berita terbongkarnya kepemilikan sel mewah oleh Arthalyta Suryani, media online detikNews.com lebih condong memberi gambaran yang lebih negatif pada sisi Arthalyta Suryani dibanding pada liputan yang lain, misalnya pada gambaran sel mewahnya atau pada penghuni sel lain selain Arthalyta Suryani yang juga memiliki fasilitas mewah.

Pencitraan negatif ini tidak terlihat pada liputan berita yang diturunkan kompas.com. media ini lebih banyak menyoroti terbongkarnya perlakuan khusus itu sendiri serta sel mewah yang dimiliki Arthalyta Suryani. Analisisnya dapat dilihat berikut ini.

Tabel 2
\begin{tabular}{|r|l|l|c|}
\hline No. & Jenis Appraisal & Contoh Kalimat & Prosentase \\
\hline 1 & Amplified: intensifier & Napi berdasi & $26 \%$ \\
\hline 2 & Affect: negatif & Fakta mencengangkan & $45 \%$ \\
\hline 3 & Affect: negatif & Kamar mewah & $29 \%$ \\
\hline & & Jumlah & $100 \%$ \\
\hline
\end{tabular}

khusus pada Arthalyta Suryani saja, karena faktanya memang terdapat tahanan lain yang memiliki sel mewah selain Ayin, bahkan lebih mewah.

Dari tabel 2 di atas, terlihat jelas sekali perbedaan penyajian liputan berita antara kompas.com dan detikNews.com. pada media kompas.com, semua hal yang berkaitan dengan kasus terbongkarnya perlakuan istimewa pada tahanan ikut disorot 
termasuk di dalamnya adalah kasus itu sendiri, sel mewah yang dikatakan bak hotel berbintang serta para tahanan yang memiliki sel mewah tersebut, ini dapat dilihat dari prosentase masingmasingnya seperti dapat di lihat di tabel 2 kalimat 1, 2 dan 3 semuanya bernada negatif terhadap objek yang dikenai appraisal, sedangkan sumber appraisal selain dari wartawan juga berasal dari nara sumber yang pendapatnya dikutip.

Kalimat 1 berasal dari kutipan nara sumber yaitu Arswendo Atmowiloto (11/20:22/kompas) yang dimintai pendapatnya mengenai kasus terbongkarnya perlakuan istimewa terhadap tahanan di Rutan Pondok Bambu. Kompas.com sendiri memberikan appraisal tersendiri untuk menjuluki sosok Arthalyta Suryani yaitu 'Ratu Lobi' (11/10:27/kompas). Julukan tersebut berkenaan dengan kemampuan Ayin dalam hal melakukan 'terobosan-terobosan hukum' atau lobi dan bukannya berkenaan dengan penampilan fisik Ayin yang sangat jelas disorot oleh detikNews.com suka berdandan dengan make up tebal walaupun berada dalam penjara. Sehingga jelas perbedaan sisi mana dari sosok Ayin yang disorot kedua media online ini.

Dari penjelasana di atas, peneliti berkesimpulan bahwa berita-berita yang diturunkan oleh media online kompas.com lebih netral dibanding detikNews.com. netral dalam arti, tidak ada salah satu aspek dari liputan beritanya tentang kasus terbongkarnya perlakuan istimewa terhadap tahanan di Rutan Pondok Bambu yang menyudutkan salah satu pihak saja, semua hal yang berkaitan dengan kasus tersebut ikut disorot da dibahas dengan pilihan bahasa yang netral dan cukup hati-hati. Misalnya menyebut Ayin hanya dengan julukan 'Ratu Lobi' (11/10:27/kompas), sel mewah yang ada di Rutan Pondok Bambu dengan 'fasilitas super mewah (11/16:55) atau 'kamar istimewa' (11/12:21) atau 'furnitur mewah' (11/06:21). Sedangkan kata-kata yang digunakan untuk kasus terbongkarnya perlakuan istimewa adalah 'kasusnya terang benderang' (11/10:27), 'Praktik kotor' (11/20:22) yang kebanyakan menggunakan penyangatan.

\section{Modalitas}

Modalitas berkaitan dengan Appraisal, berikut akan disajikan analisis modalitas yang ada pada data baik di kompas.com maupun di detikNews.com

Judul berita: Din Syamsudin: Kasus Sel Ayin Cuma Puncak Gunung Es (12/13:05/kompas):

Ini sungguh menghentak dan mengusik rasa keadilan....tidak mungkin kalau tidak ada bantuan dukungan dari pejabat terkait. Jadi harus diusut dan ditindak tegas...

Modalitas pada kalimat (12/13:05/kompas) sangat kuat karena di situ tergambar kemungkinan yang sangat kuat bahwa kepemilikan sel mewah oleh Arthalyta Suryani pasti mendapat dukungan dari pejabat terkait. Ini akan berbeda jika kalimatnya sebagai berikut:

Ini sungguh menghentak dan mengusik rasa keadilan.... mungkin ada bantuan dukungan dari pejabat terkait. Jadi harus diusut dan ditindak tegas...

Kalimat di atas tersirat keraguan bahwa kepemilikan sel mewah atas Arthalyta Suryani mendapat dukungan dari pejabat terkait dengan penggunaan kata 'mungkin'.

Judul berita: Ayin Harus
Dipindah ke Sel Khusus di
Nusakambangan (11/11:56/detik)
Ini pasti ada konspirasi di dalamnya...
Kata 'pasti' pada kalimat di atas
merupakan penanda bahwa


kemungkinan adanya konspirasi dalam kepemilikan sel mewah oleh arthalyta Suryani dapat dinegosiasikan. Kalimat ini akan terasa berbeda jika unsur negosiasi tersebut dihilangkan seperti pada kalimat di bawah ini:

Ini ada konspirasi di dalamnya...

Kata 'ada' konspirasi tanda ada kata 'pasti' menandakan bahwa tidak ada kemungkinan negosiasi makna pada kalimat tersebut, artinya memang telah terbukti bahwa ada konspirasi dalam kepemilikan sel mewah oleh Arthalyta Suryani.

Keberadaan modalitas pada teks berita terbongkarnya perlakuan istimewa terhadap terpidana suap Arthalyta Suryani pada media kompas.com dan detikNews.com seimbang artinya tidak ada yang lebih menonjol satu dari yang lain.

\section{Genre teks berita}

\section{a). Cerita Ayin Mengatur Negeri dari} Balik Jeruji (11/19:22/detik)

Tiap media pasti memiliki interpretasi yang berbeda pada tiap beritanya. Demikian halnya dengan berita mengenai terbongkarnya keberadaan sel mewah di Rutan Pondok Bambu, misalnya, media detikNews.com dengan tipe genre news item $^{3}$ menganggap bahwa liputan mengenai kepemilikan sel mewah oleh Arthalyta Suryani lebih menarik dikupas dan ditonjolkan ketimbang liputan mengenai deskripsi sel mewah di Rutan Pondok Bambu ala kompas.com, karena berita mengenai Arthalyta Suryani dirasa cukup menjual mengingat Ayin disangkutkan dengan kasus suap tersebut. Hal ini kemudian diperkuat dengan pendapat nara sumber yaitu, Syamsu, mantan Jamintel Kejagung yang menjadi saksi kehebatan
Ayin membuat terobosan hukum meski berada dalam penjara pada kasus manipulasi kepemilikan tanah seluas $5.100 \mathrm{~m}^{2}$ di seberang Ratu Plaza Jakarta.

\section{b). Arthalyta Suryani Sedang Dirawat Wajahnya oleh Dokter Spesialis (11/06:21/kompas)}

Interpretasi kompas.com atas berita terbongkarnya keberadaan sel mewah di Rutan Pondok Bambu adalah dengan mendeskripsikan sel mewah tersebut (ini sesuai dengan tipe genre teks berita kompas.com pada liputan berita ini yaitu deskripsi) karena media ini menganggap keberadaan sel mewah tersebut sudah merupakan berita yang cukup menjual dan menarik mengingat selama ini, sel tahanan selalu identik dengan tempat yang dihuni secara 'berdesak-desakan' dan penuh dengan ketidaknyamanan, sehingga dianggap sesuatu yang mencengangkan bila ternyata terdapat sel berukuran $8 \times 8$ yang dilengkapi dengan sejumlah fasilitas mewah semisal AC dan spring bed yang dimiliki oleh beberapa narapidana ${ }^{4}$.

Perbedaan interpretasi atas berita terbongkarnya keberadaan sel mewah di Rutan Pondok Bambu sesuai dengan tipe genre yang dimiliki kedua media di atas sama dengan perbedaan tema yang dianggap penting oleh kedua media tersebut. Semua pemilihan tersebut disesuaikan dengan ideologi media serta target pembaca yang hendak dibidik. DetikNews.com yang penyajian beritanya singkat dan tidak mendalam, diperuntukkan bagi orang-orang yang hanya ingin tahu mengenai informasi apa yang sedang aktual dibicarakan, sedangkan Kompas.com dengan liputan berita yang mendalam diperuntukkan bagi pembaca yang komprehensif.

\footnotetext{
${ }^{3}$ Analisis lebih rinci mengenai genre dapat dilihat di lampiran 2.
}

${ }^{4}$ Analisis lebih rinci dapat dilihat di lampiran 1. 
Intertekstualitas

\section{a). Cerita Ayin Mengatur Negeri dari Balik Jeruji (11/19:22/detik)}

Intertekstualitas menyatakan

adanya hubungan antar teks dalam teks dan hubungan teks dengan teks lain di luar teks tersebut. Ibarat sebuah buku, maka teks-teks dalam tiap babnya harus berhubungan, demikian juga dengan setiap bab dalam buku tersebut.

Intertekstualitas yang terdapat pada teks berita detikNews.com adalah intertekstual yang tercipta dengan melakukan kutipan-kutipan dari teks berita lain atau kutipan-kutipan dari narasumber (penamaan atau referensi). Salah satu contohnya bisa dilihat pada teks berita detikNews.com yang berjudul Cerita Ayin Mengatur Negeri dari Balik Jeruji (11/19:22) yang mengutip pendapat Syamsu, mantan jamintel Kejagung berikut ini:

“Tetapi Ayin lewat PT GMN berhasil memutar fakta sehingga mampu merebut tanah itu. PT GMN itu anak perusahaan Gajah Tunggal milik Syamsul Nursalim. Padahal ia masih di penjara," imbuhnya. Modusnya, ucap Syamsu, Ayin membuat terobosan hukum. Ia mengajukan sejumlah upaya hukum hingga Pemprov DKI Jakarta menerbitkan SIPT dan HGB kepada PT GMN di atas lahan serupa.

Sesuai dengan judul teks yang ingin menyatakan bahwa Ayin masih dapat berbuat banyak (melakukan terobosan-terobosan hukum) meski berada dalam penjara, maka isi teks tersebut memberi penjelasan bagaimana Ayin melakukan terobosanterobosan tersebut yaitu dengan melakukan pendekatan-pendekatan hukum pada para petinggi hukum dan pihak-pihak berwenang yang dapat membantu mengubah surat kepemilikan tanah seluas $5100 \mathrm{~m}^{2}$ yang berada di seberang Ratu Plaza Jakarta dari PT
HArangganjang menjadi milik PT GMN.

Kajian yang lugas dan straighforward seperti yang disajikan detikNews.com sesuai dengan pembaca yang sibuk dan hanya ingin membaca sekilas. Walaupun kajiannya tidak mendalam dan lengkap, tapi berita tersebut telah cukup memberi informasi tentang berita yang sedang aktual saat itu.

\section{b). Arthalyta Suryani Sedang Dirawat Wajahnya oleh Dokter Spesialis (11/06:21/kompas)}

Intertekstualitas yang terdapat pada teks berita kompas.com tercipta dengan empat cara, yaitu mengutip pendapat dari sumber atau teks lain, referensi, asosiasi proksimal dan asosiasi sekuensial. Hubungan itu tidak hanya terjadi dalam satu teks saja, namun pada keseluruhan teks berita yang bertemakan terbongkarnya keberadaan sel mewah di Rutan Pondok Bambu.

Pada teks berita Arthalyta Suryani Sedang Dirawat Wajahnya oleh Dokter Spesialis (11/06:21/kompas) hubungan asosiasi proksimal yang terjadi antar teks sangat jelas terlihat. Misalnya pada kalimat berikut ini:

Inspeksi mendadak oleh anggota Satuan Tugas Pemberantasan Mafia Hukum, Minggu (10/1/2010) malam, di Rumah Tahanan Khusus Wanita Kelas II A Pondok Bambu, Jakarta Timur, menemukan sejumlah fakta mencengangkan.

Fakta-fakta yang dianggap mencengangkan tadi kemudian dijelaskan pada paragraf selanjutnya:

Sejumlah... gedung perkantoran... disulap menjadi ruang pribadi mewah yang dipakai beberapa narapidana narapidana.

Keterangan tersebut ditambah dengan kutipan narasumber 
(intertekstual penamaan atau referensi), yaitu Yunus, salah satu anggota satgas Pemberantasan Mafia Hukum yang ikut menginspeksi Rutan Pondok Bambu dan menemukan keberadaan sel mewah di Rutan tersebut.

"Tadinya saya cuma denger ada fasilitas mewah diberikan kepada narapidana, .......ternyata jauh lebih besar."

Sedangkan ruang pribadi mewah yang dipakai beberapa narapidana yang disebutkan di teks tersebut, dijelaskan pada berita selanjutnya (11/10:27/kompas) dengan judul Pramono: Pecat Kepala Rutan Pondok Bambu! Dengan teksnya:

Ketika ditemui, Ayin,....di ruang seluas 8 meter $x \quad 8$ meter yang dihuni Ayin....terdapat kulkas, TV layar datar, dan penyejuk ruangan... Sementara itu, di ruangan Limarita, malah terdapat ruang karaoke khusus yang mewah.

Deskripsi sel mewah tersebut dijelaskan kembali lebih detail pada teks berita (11/11:34/kompas) dengan judul Ini Dia Fasilitas di Ruang Tahanan Arthalyta. Teksnya sebagai berikut:

Saat Kompas.com melihat langsung...sejumlah fasilitas mewah terlihat di ruang tahanan Arthalyta...televisi flat merek Samsung 21 inci, pendingin ruangan portable.... Intertekstualitas (asosiasi proksimal) yang lain pada teks berita Arthalyta Suryani Sedang Dirawat Wajahnya oleh Dokter Spesialis yang dimuat di media online kompas.com (11/06:21/kompas) pada kalimat berikut ini:

Sementara itu, ruangan Limarita berada di lantai dua. Dalam pengamatan Kompas, orang luar dipastikan tidak akan menyangka bahwa ruangan di gedung perkantoran tersebut "dialihfungsikan" menjadi ruang tahanan mewah.....
Berita mengenai pihak luar (warga sekitar) yang tidak mengetahui keberadaan sel mewah di Rutan Pondok Bambu diturunkan senin (11/14:41/kompas) dengan judul Warga Tak Tahu Fasilitas Mewah di Rutan Pondok Bambu. Pada berita tersebut dikutip pendapat seorang perempuan penjual kopi di sekitar lingkungan rutan dengan logat Sundanya yang kental

Tidak tahu, sumpah deh. Tahunya di dalam itu ya rutan saja.

Bentuk intertekstualitas asosiasi sekuensial juga terdapat pada teks berita Arthalyta Suryani Sedang Dirawat Wajahnya oleh Dokter Spesialis yang dimuat di media online kompas.com (11/06:21/kompas) pada kalimat berikut ini:

Saat akan memasuki gedung rumah tahanan, para anggota satuan tugas dan sejumlah wartawan yang ikut sempat nyaris bersitegang dengan sejumlah petugas rumah tahanan.

Jawaban atas 'kata bersitegang' didapat pada liputan berita yang diturunkan Senin (11/12:21/kompas) dengan judul berita Rutan Pondok Bambu Bantah Ada fasilitas Mewah, dengan kutipan berikut ini:

Tidak ada (permintaan khusus). Perlakuan khusus itu juga tidak ada karena ada bon-bonnya. Anda bisa lihat bon-bon sebelumnya.

Bantahan tersebut juga memiliki kolerasi dengan liputan berikutnya yang diturunkan Senin (11/11:24/kompas) dengan judul Dirjen Lapas Bantah Ada Fasilitas Mewah di Rutan Pondok Bambu.

Kita tidak ada yang ditutupi. Kalau saya pikir sekarang fungsi ruangan ini sudah benar. Tidak ada perlakuan khusus pada tahanan. Kalau terselip mainan anak itu wajar.

Kalimat di atas sebagai jawaban atas berita pada teks berita Arthalyta Suryani Sedang Dirawat Wajahnya oleh 
Dokter Spesialis yang dimuat di media online kompas.com (11/06:21/kompas) tentang ditemukannya tempat tidur bayi dan dewasa serta mainan anak-anak di kamar Arthalyta Suryani.

Di ruangan Limarita...di kamar Arthalyta terdapat beberapa macam permainan anak-anak dan tempat tidur bayi dan dewasa.

\section{Simpulan}

\section{Hasil Simpulan}

Dari hasil analisis data teks berita mengenai terbongkarnya perlakuan istimewa terhadap terpidana suap Arthalyta Suryani dapat disimpulkan bahwa untuk liputan berita yang sama, masing-masing media memiliki caranya tersendiri untuk menyampaikan informasi tersebut kepada khalayak agar mudah dimengerti. Perbedaan cara ini menyangkut perbedaan pilihan kosakata yang digunakan pada teks berita, perbedaan genre teks serta intertekstualitas yang dipengaruhi oleh ideologi masing-masing media. Ideologi ini bersangkut paut dengan target pembaca yang hendak dibidik.

DetikNews.com yang memiliki pilihan kosakata yang berani, tajam dan lugas cocok untuk jenis genre News item, karena genre ini mengedepankan keaktualitasan berita. Diperlukan topik yang benar-benar menarik sehingga mampu mengundang perhatian pembaca. Oleh karena itu, liputan beritanya lebih banyak menyoroti sosok Arthalyta Suryani dibanding kasus terbongkarnya perlakuan istimewa itu sendiri maupun keberadaan sel mewah yang dimilikinya, hal ini karena Ayin telah dikenal sebelumnya sebagai tukang suap, yang artinya kepemilikan sel mewah tersebut dapat dikaitkan dengan suap yang mungkin dia lakukan untuk memperoleh fasilitas mewah tersebut. Isi berita yang singkat dan lugas, sangat cocok diperuntukkan bagi pembaca yang sibuk, yang hanya punya waktu sekilas untuk mengetahui informasi apa yang aktual saat itu.

Sedangkan kompas.com yang liputannya mendalam dan lengkap, dengan pilihan kosakata yang netral dan hati-hati sesuai bagi pembaca yang komprehensif, pembaca yang benarbenar ingin menyimak hal apa yang sedang dibicarakan serta bagaimana serta kenapa. Pembaca yang peduli akan keobjektifan berita, hal ini sesuai dengan ideologi kompas.com yang memang hati-hati dalam pilihan kosakata serta netral dalam penyajian liputan beritanya. Ini dapat dilihat pada sistem appraisal yang digunakan kompas.com yaitu menyoroti semua sudut yang bersangkut paut dengan keberadaan sel mewah di Rutan Pondok Bambu kemudian mendeskripsikannya secara netral dan rinci tanpa ada tendensi untuk hanya menonjolkan salah satu bagian saja dari kasus tersebut.

\section{Daftar Pustaka}

Black, Elizabeth. 2006. Pragmatics Stylistics. Edinburgh: Edinburgh University Press.

Eggins, Suzanne. 1994. An Introduction to Systemic Functional Linguistics. London: Pinter Publishing.

Eriyanto. 2000. Analisis Wacana. Malang: LkiS.

\section{Framing} Analisis. Yogyakarta: LkiS.

Fairclough, Norman. 1989. Language and Power. London: Longman. 1994. Discourse and Social Change. London: Blackwell Publish. 2003. Language and Power: Relasi Bahasa, Kekuasaan dan Ideologi. 
Malang: Boyan Publishing (terjemahan).

Gerot, Linda and Wignell, Peter. 1994. Making Sense of Functional Grammar: An Introductory Workbook. Sidney: Gerd Stabler.

Hodge, Robert and Kress, Gunther. Language As Ideology. 1979. London: Routledge.

Krippendorff, Klaus. 2004. Content Analysis: An Introduction to Its Methodology. London: Sage Publications.

eharto. A 32- years Period of Indonesian Presidency. Germany: VDM Verlag Dr. Muller Aktiengesell Schaft \& Co. KP

Renkema, Jan. 1993. Discourse Studies: An Introductory Textbook. Amsterdam: John Benjamin Publishing Company.

Simpson, Paul. 1993. Langauge, Ideology and Point of View. London: Routledge.
Kusuma, Jati, T.M. 2007. Pengantar (Metode) Penelitian Bahasa. Yogyakarta: Carasvatibooks.

Martin, J.R and Rose, David. 2003. Working With Discourse: Meaning Beyond the Clause. London: Continuum.

Nunan, David. 1993. Discourse Analysis. London: Penguin.

Purwanto, Sugeng. 2009. Around the Fall of So

Thomson, Geoff. 1996. Introducing Functional Grammar. London: Arnold.

Van Djik, Teun A. 1985. Handbook to Discourse Analysis: Volume 2. Dimension of Discourse. London: Academic Press Inc.

Yule, George. 1996. Pragmatics. New York: Oxford University Press.

http://www.answers.com/topic/literacyintertextuality 